\title{
Prevalence and Scabies Severity Rate on a Goat at Mempawah Hilir, Mempawah District West Kalimantan Province
}

\author{
${ }^{1)}$ Arum Maula Hidayah, ${ }^{2)}$ Wiwiek Tyasningsih ${ }^{(0,3)}$ Soeharsono, ${ }^{4)}$ Retno Wulansari \\ ${ }^{1)}$ Student, Faculty of Veterinary Medicine, Universitas Airlangga, arum.maula@yahoo.com \\ ${ }^{2)}$ Division of Veterinary Microbiology, Faculty of Veterinary Medicine, Universitas Airlangga, \\ ${ }^{3}$ Division of Veterinary Anatomy, Faculty of Veterinary Medicine, Universitas Airlangga, \\ ${ }^{4)}$ Veterinary Internal Medicine Division, Department of Clinic, Reproduction and Pathology, Faculty of \\ Veterinary Medicine, IPB University. \\ Corresponding author: wiwiek-t@fkh.unair.ac.id
}

\begin{abstract}
This research aims to determine the prevalence and severity rate of scabies on goats in Sub-District of Mempawah Hilir, Mempawah, West Kalimantan. The goat livestock used were not determined by age, sex, and breed. The number of goats researched was 100 goats. Scabies prevalence measurement was to divide the number of scabies goats by total goats, then multiplied by $100 \%$ and measurement of the severity rate of scabies goats with scoring with grades 1-3 (low), 4-6 (moderate), and 7-9 (heavy). The results obtained scabies prevalence rate of $38 \%$ with 38 positive samples from a population of 100 goats and the percentage of severity was $42 \%$, moderate $24 \%$, and $34 \%$ severe. This is due to weather factors in the area and the type of cage as well as inadequate maintenance management, thus making many cases of scabies attack goats.
\end{abstract}

Keywords: prevalence, severity, goats, scabies, Mempawah Hilir, skin disease.

\section{Introduction}

Goats are one of the small ruminants that are often affected by scabies. Scabies is a skin disease caused by Sarcoptes scabiei (S. scabiei) in animals that can cause dermatitis or cause infection in animals that causes damage to the affected skin and causes anxiety in animal sufferers (Iskandar, 2000). Scabies is even zoonotic or can attack humans and is associated with the immune system (Lastuti et al., 2018). According to Orisa et al., (2014) stress is one of the factors that can cause goats to be susceptible to disease, the stress factor is due to the density of the population in livestock that are placed in one cage, decreased feed quality and unhygienic dirty cages, if left unchecked the impact from stress can slowly kill farm animals. Goats that are never bathed, brushed, and their cages are never sanitized and cleaned can facilitate transmission between cattle infected with scabies to healthy livestock (Andoko and Warsito, 2013).

Transmission of $S$. scabiei can occur if there is direct contact with larvae, nymphs, and fertile female mites either from the skin surface directly or from objects infected with $S$. scabiei (Sasmita et al., 2005). Morphologically, the most sensitive part of scabies attack is the ear, because the layer of the earlobe is a relatively thin skin and not much covered with hair so that $S$. scabiei mites easily live and breed (Eleser et al., 2005).

According to a report from the Department of Agriculture, Food Security and Fisheries of Mempawah District, scabies cases in Mempawah reached 246 cases from March 2017 to May 2020 and reached the highest case in 2020 with 114 cases, 2017 was 76 cases, 2018 reached 31 cases, and in 2019, there were only 25 cases of scabies. The Department of Agriculture, Food Security and Fisheries of Mempawah District explained that the population of goats in Mempawah Hilir SubDistrict in December 2019 had reached 1435 heads.

This study was conducted to determine the prevalence of scabies and the level of the severity of scabies in goats in Mempawah Hilir Sub-District, Mempawah District. The results of this study are used as data as information to determine the right method of prevention and treatment control in cases of scabies.

\section{Materials and Methods}

This research is an observational study with laboratory exploration followed by SPSS 
analysis with tree regression method. The variables observed in this study were goats with no specified age, sex, and breed of goat. Sampling was carried out in the Mempawah Hilir Sub-District, Mempawah District which included 3 Villages, namely Terusan Village, Tengah Village, Tanjung and 5 Villages, namely Pasir Village, Sengkubang Village, Malikian Village, Penibung Village, and Kuala Secapah Village. Sample examination was carried out at the Parasitology Laboratory of the Faculty of Veterinary Medicine, Universitas Airlangga. Severity rate is a measure of the severity of scabies in goats which can be seen from clinical symptoms, namely crusting and alopecia in several body regions.

\section{Research Procedure}

Sampling was randomly divided into 5 villages. The positive goats were scraped using a sterile scalpel, the scabs on the goat skin were scraped until they bleed, then the scrapping samples were put into a petri dish containing $0.9 \%$ sodium chloride for microscopic examination. The results of scrapings that have been clarified with $10 \% \mathrm{KOH}$ solution, then placed on an object glass, then covered with a cover glass and examined under a microscope on 40 to 100 magnifications. The results were declared positive if the morphology of the $S$. scabiei was found and the results were declared negative if the $S$. scabiei was not found (Soulsby, 1986).

\section{Research Materials and Tools}

This study uses materials and tools, including: $0.9 \%$ sodium chloride, $70 \%$ alcohol, and iodine tincture, gloves, cotton, petri dishes, scalpel, pipette or disposable syringe, object glass, cover glass, and a microscope.

\section{Data Analysis}

according to Davis et al, (2013), there is no standard way to describe the severity of a scabies crust or scab. However, a clinical rating scale has been developed using a scale to determine the severity of the infestation according to the grade grade 1,2 , or 3 indicating mild, moderate or severe severity based on the distribution and extent of crusting, crusting thickness, history of disease occurrence, and skin condition. In this study, the severity was assessed based on the division of the body region by taking into account the clinical symptoms such as alopecia and crusting. The distribution of grades/levels and scores is as shown in Table 1.

\section{Result and Discussion}

The prevalence rate of scabies in goats in Mempawah Hilir Sub-District, Mempawah District was $38 \%$ with 38 positive samples from a total population of 100 goats. Goats experience clinical symptoms of scabies in the form of crusts on the facial region which includes the mouth, nose, eyes and ears, as well as alopecia and crusts are also found in the leg region which includes the forelegs and hind legs. The results of the clinical examination can be seen in Figure 1.

Table 1. Scabies Severity Scoring (Davis et al, 2013)

\begin{tabular}{lll}
\hline \multicolumn{1}{c}{ Body region } & \multicolumn{1}{c}{ Clinical symptoms } & \multicolumn{1}{c}{ Score } \\
\hline 1. Facial region (mouth, & 1.1 There is mild alopecia $(\mathrm{o}-1 \mathrm{~cm})$ & 1 \\
nose, eyes and ears) & 1.2 There is severe alopecia $(>1 \mathrm{~cm})$ & 2 \\
& 1.3 There is treatment $(\mathrm{crust})$ & 3 \\
& 2.1 There is mild alopecia $(\mathrm{o}-1 \mathrm{~cm})$ & 1 \\
2. Foot region (front and & 2.2 There is severe alopecia $(>1 \mathrm{~cm})$ & 3 \\
hind legs) & 2.3 There is treatment (crust) & 1 \\
& 3.1 There is mild alopecia $(\mathrm{o}-1 \mathrm{~cm})$ & 2 \\
3. Body region (in areas & 3.2 There is severe alopecia $(>1 \mathrm{~cm})$ & 3 \\
other than face and feet) & 3.3 There is treatment (crust) & \\
&
\end{tabular}




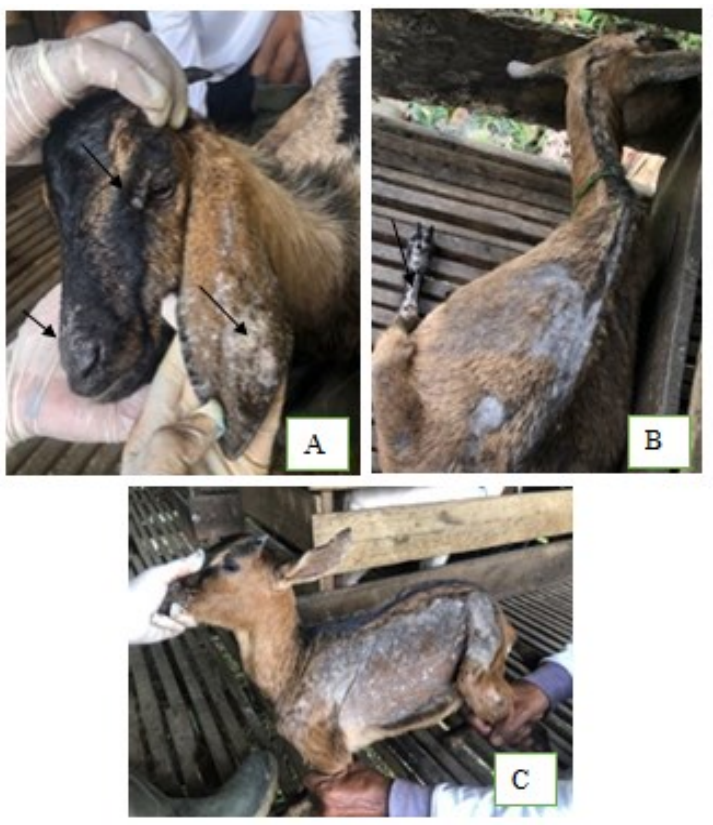

Figure 1. Clinical examination of scabies goats, including the face and extremities.

Microscopic examination of goat skin scraping shows the presence of $S$. scabiei which grows and breeds on the surface of goat skin, resulting in scabies which can be seen in Figure 2. The results of goat skin scraping which has clinical symptoms of scabies in various stages of development of $S$. scabiei seen in Figure 3.

The results of the assessment of the severity of scabies crusts based on the division of the goat's body region with crusts and alopecia, 38 samples of goats obtained positive results. The percentage of severity is classified as mild $45 \%$ with clinical symptoms only found alopecia and crusting in the facial region which includes the mouth, nose, eyes, and ears. The percentage of moderate severity is $21 \%$, with clinical symptoms of alopecia and crusting in the facial region and accompanied by the goat's leg region as well as the front or hind legs. As for the severity group, it is classified as severe because there is alopecia and crusting in the facial region, leg region, and body region with a percentage of $34 \%$. The severity of scabies in this study is shown in Figure 4.

Clinical symptoms with mild severity in the form of crusting and alopecia in the facial region which includes the area of the mouth, eyes, nose, and ears. Goats with moderate severity have clinical symptoms, namely alopecia and crusting in the face and body regions of goats experiencing alopecia. In addition, there is also a severe severity level that has clinical symptoms of crusting and alopecia on the face, legs (forefoot and hind legs), and on the body area of the goat's body.

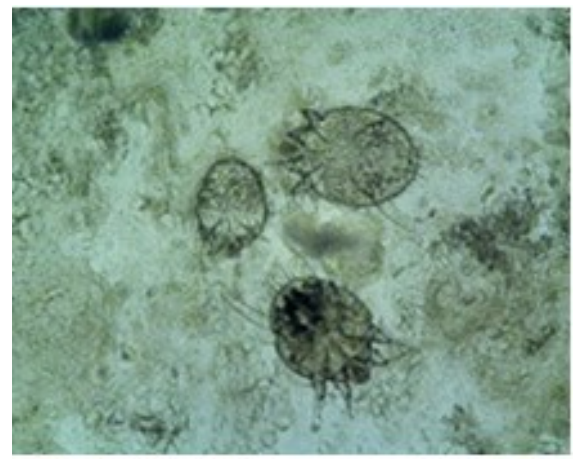

Figure 2. Sarcoptes scabiei was seen on the results of native skin scrapings under a microscope with a magnification of 10ox.

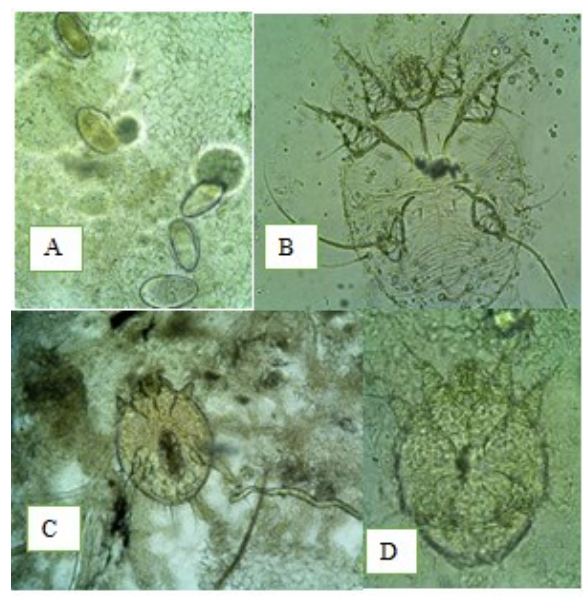

Figure 3. The results of skin scrapings showed that $S$. scabiei was in the developmental stage (a) eggs; (b) larvae; (c) nymphs; (d) adult. 


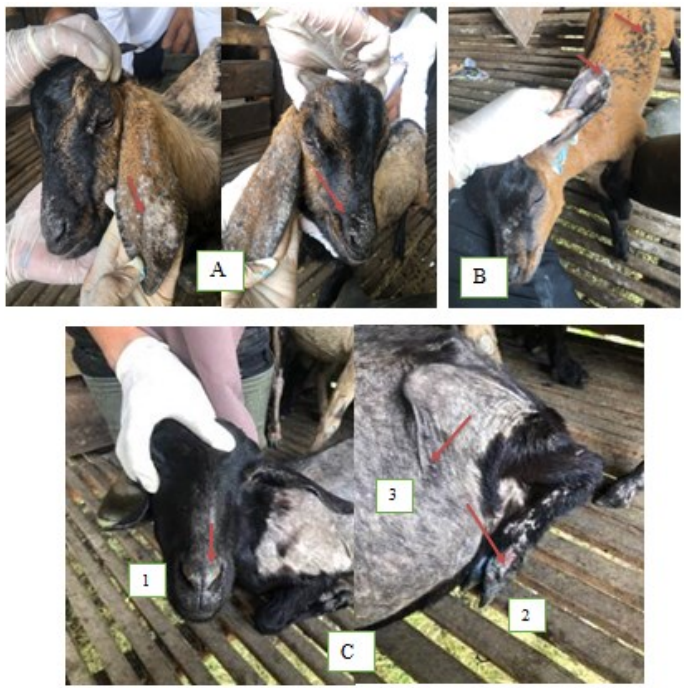

Figure 4. The severity rate of goat scabies is (a) mild, (b) moderate, (c) severe: 1) the facial region has crusting, 2) the leg region has crusting, alopecia, and hypersensitivity, 3) the extremity region has alopecia and crusting.

The spread of scabies lesions in goats, seen from Figure 5 has the most spread around the ears. The places of spread of the highest number of lesions were consecutively on the front legs, eyes, hind legs, nose, dorsal body legs, mouth, and finally the lesions with the fewest lesions were on the ventral body of the goat.

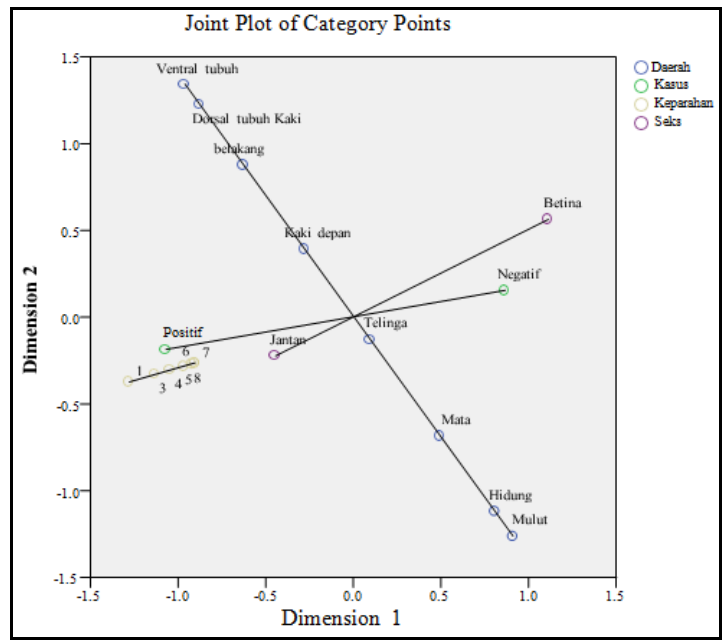

Figure 5. Diagram of the spread of scabies lesions in goats

The results showed that the prevalence rate of scabies in goats in Mempawah Hilir SubDistrict, Mempawah District, West Kalimantan Province was $38 \%$ with 38 positive samples from a total of 100 samples taken randomly. In accordance Handoko (2001) macroscopic examination is very necessary because clinical examination is the basic examination to diagnose the presence of $S$. scabiei in crusts and microscopic examination is carried out with a magnification of 40-100 times. Diagnosis through clinical symptoms of scabies needs to be done differential diagnosis. In some cases, the differential diagnosis of scabies resembles that of systemic lupus erythematosus, bullous pemphigoid, Langerhans cell histiocytosis, urticaria pigmentosa, and seborrheic dermatitis. Crusted scabies can also mimic psoriasis (Heukelbach and Feldmeier, 2006). Goats found clinical symptoms of alopecia, erythema, papules, scabies crust formation or hyperkeratosis and pruritus or itching in the hump, neck, forehead and head area. This symptom is a common clinical symptom in cases of scabies in goats (Kumar et al. 2014). Ahmad (2004) reported that $S$. scabiei can live at a temperature of $20-30^{\circ} \mathrm{C}$ with a humidity of 40-50\%. Hartati (2001) also reported in his study that low ambient temperatures of $\mathbf{2 0}-22^{\circ} \mathrm{C}$, fairly high rainfall $(1918 \mathrm{~mm} /$ year $)$ and high humidity are good places for the growth of mites. This is supported by the weather conditions in Mempawah Hilir Sub-District, Mempawah District according to the Meteorology, Climatology and Geophysics Agency of West Kalimantan Province (2019), Mempawah Hilir Sub-District has an average air temperature of $21{ }^{\circ} \mathrm{C}$ and has an average rainfall of $338.5 \mathrm{~mm}$ and rainy days an average of 17 days per month. Poor sanitation and environment are also suspected to be the main factors in the transmission of this disease. This is in accordance with that reported by Marimuthu et al. (2015) that the transmission of mites that can be transmitted quickly is through direct contact between goats with one another. The severity level was classified as mild, amounting to 16 of 38 positives. The level of severity classified as moderate is 9 goats while the sample classified as severe severity is 13 goats. Alopecia and crusting characterize the clinical symptoms of scabies, according to Davis et al., (2013) the scabies score is divided into 4 components, namely the distribution and area of crusts, crust thickness, history of disease occurrence, and skin conditions and the percentage of scabies crusts. The course of scabies according to Morsy et al., (1989) is divided into 4 phases, namely the first phase, occurring 1-2 days after infestation. The first phase of the mite begins to penetrate the epidermis layer causing the skin surface to have 
many small holes. The second phase, $S$. scabiei is under the keratin layer, the skin surface has been covered by a thick crust / scab. Hair loss occurs in the second phase and occurs after 4-7 weeks of infestation. The third phase the crusts begin to peel, so that on the surface of the skin it repeats itself which causes small holes in the epidermis layer. This last phase occurs 7-8 weeks after the infestation, it appears some mites leave the scars of the hole.

\section{Conclusions}

The prevalence rate of scabies in goats in Mempawah Hilir Sub-District, Mempawah District was $38 \%$. The severity rate of scabies in goats in Mempawah Hilir Sub-District, Mempawah District was divided into 3, namely the severity level, namely mild, moderate, and severe. The percentage of mild severity was $45 \%$, moderate severity was $21 \%$, and severe severity was $34 \%$. Regular counseling and assistance to farmers in order to further improve the management of goat rearing, so that they pay more attention to cage sanitation and management, as well as environmental cleanliness around the cage. The importance of the presence of veterinarians and paramedics to be placed in the area due to the lack of veterinarians and paramedics is also a factor in the high incidence of a disease, especially scabies in Mempawah Hilir Sub-District, Mempawah District, West Kalimantan Province.

\section{References}

Ahmad, R. Z. 2004. Cendawan Metarhizium Anisopliae Sebagai Pengendali Hayati Ektoparasit Caplak dan Tungau Pada Ternak. Wartazoa. 14(2): 73-78.

Andoko, A dan Warsito. 2013. Beternak Kambing Unggul. PT Argomedia Pustaka. Jakarata Selatan.

Davis, J. S., S. Mc Gloughlin, S.Y.C. Tong, S.F. Walton, and B.J. Currie. 2013. A Novel Clinical Grading Scale to Guide The Management of Crusted Scabies. Plos Neglected Tropical Disease 7(9): E2387. Department of Health: Canbera.

Eleser, S., J. Junjungan, Manurung, dan T. Suibu. 2005. Efektivitas Pemberian Monolaurin Dan Obat Alternatif Lainnya Dalam Memberantas Penyakit Skabies Pada Kambing. Pros. Seminar Nasional Peternakan Dan Teknologi Veteriner,
Bogor, 12-13 September 2005. Puslitbang Peternakan, Bogor. 941-945.

Handoko, R. 2001. Diagnosis Skabies Dengan Laboratorium dan Tinta. Maj. Parasitol. Ind. 2(3\&4): 91- 96.

Hartati, N. 20o1. Studi Kasus Skabies Pada Kambing Di Kelompok Peternak Kambing Simpay Tampomas Sumedang Jawa Barat [Skripsi]. Bogor (ID). Institut Pertanian Bogor.

Heukelbach, J. and Feldmeier, H. 2006. Scabies. The Lancet. Vol 367.

Iskandar, T. 200o. Masalah Skabies pada Hewan dan Manusia Serta Penanggulangannya. Wartazoa. 10: 28-34.

Kumar, M., B. Pal., R.D. Purkayastha., and J. Roy. (2014). Clinico Pathological and Therapeutic Ecaluation of Black Bengal Goats (Capra Hircus) Infested with Psoroptes Caniculi, 40(1): 41-45.

Lastuti, N.D.R., Hatutiek, Suwanti, and Chrismanto. 2018. Exploration of Sarcoptes Scabiei Antigenic Protein Which Play Roles In Scabies Pathogenesis In Goats And Rabbits. Iran. J. Parasitol., 13(3): 466472.

Marimuthu, M., F.F.J. Abdullah., K. Mohammed., L.A Tijjani., Y. Abba., M.A. Sidiq., L.Y. Ting., A.A. Saharee., and A.W. Harron. 2015. Comperative Treatment Approach for Sarcoptes and Psoroptes Mite Infestasion In Boer Cross. J. Adv.Vet. Anim. Res. 2(1): 84-88. Doi: 10.5455/Javar.2015.B46.

Morsy, G.H., J.J. Turek and S.M. Gaafar. 1989. Scanning Electron Microscopy of Sarcoptic Mange Lesions in Swine. Vet. Parasitol. 31: 281-288.

Orisa, M., P.B Santoso, dan O. Setyawati. 2014. Sistem Pakar Diagnosis Penyakit Kambing Berbasis Web Menggunakan Metode Certainty Factor. 8(2): 151-156. Cats. Journal of Medicine and Surgery, X, 167174.

Sasmita, R., Poedji H., Agus S. dan Ririen N.W. 2005. Buku Ajar Ilmu Penyakit Arthropoda Veteriner. Laboratorium Entomologi Dan Protozoologi. Departemen Pendidikan Dan Kebudayaan Fakultas Kedokteran Hewan Universitas Airlangga. Surabaya. 
Soulsby, E. J. L. 1986. Helminth, Arthropods and Protozoa of Domesticated Animals.
The English Language Book Society and Bailliare Tindall, London. Hal 809. 